\title{
Hak-Hak Korban Pelanggaran HAM Yang Berat (Tinjauan Hukum Internasional dan Nasional)
}

\author{
Abdul Haris Samendawai \\ Jl. Latu Harhari 4 B Menteng Jakarta Pusat \\ ahsemendawai@hotmail.com
}

\begin{abstract}
The rights of the victim of serious human rights violence have been provided in various regulatory frameworks, however, conceptual flaws in the substance of law are sill apparent in our legal system. Such flaws in the substantial aspect is estimated to badly affect the implementation of the protection of the rights of victim of serious crimes against human rights, since the procedural aspects refer to the material aspect of law. This is a real challange which may push the related authorities and institutions to contribute to the effort for the protection and the development of human rights as well as the enforcement of law and justice among victims.
\end{abstract}

Keywords: Rights Of Victim, The Serious Violence Against Human Rights, International Law

\section{Pendahuluan}

Perkembangan teori-teori studi kriminologi dan hukum pidana serta praktik bekerjanya sistem peradilan pidana dalam beberapa dekade telah mengalami perubahan besar, khususnya terkait dengan perhatian para pakar, akademisi, dan praktisi terhadap kedudukan korban dalam proses peradilan pidana. Perhatian yang semakin besar terhadap posisi korban dalam peradilan pidana ditunjukkan dengan dihasilkannya berbagai aturan hukum baik di tingkat internasional maupun nasional, yang mengatur masalah perlindungan dan jaminan hak-hak korban. Di Indonesia perhatian terhadap posisi korban dalam sistem peradilan pidana semakin nyata dengan diundangkannya Undang-Undang Nomor 13 tahun 2006 tentang Perlindungan Saksi dan Korban. Dalam undangundang tersebut, terdapat tiga hal yang menjadi muatan pokok yaitu: 
Pertama, rumusan hak-hak serta bentuk-bentuk perlindungan yang diberikan kepada saksi dan korban; Kedua, aspek kelembagaan Lembaga Perlindungan Saksi dan Korban (LPSK); dan Ketiga, ketentuan mengenai pemberian perlindungan dan bantuan yang menyangkut aspek mekanisme prosedural bekerjanya LPSK.

Tulisan ini menguraikan secara ringkas perlindungan dan hak-hak korban pelanggaran hak asasi manusia yang berat yang terdapat dalam hukum hak asasi manusia internasional serta bagaimana konteks pengaturan dan pelaksanaannya dalam hukum nasional. Untuk keperluan penyusunan naskah ini, istilah pelanggaran hak asasi manusia yang berat penulis merujuk pada definisi yang terdapat pada Undang-Undang Nomor 26 tahun 2000 tentang Pengadilan Hak Asasi Manusia. Sebagai acuan pokok bahwa yurisdiksi materiil Undang-undang tentang Pengadilan Hak Asasi Manusia adalah menunjuk dua jenis tindak pidana yakni genosida dan kejahatan terhadap kemanusiaan sebagai pelanggaran hak asasi manusia yang berat. Dalam konteks penegakan hukum, tentunya akan muncul kerumitan yang bisa jadi bersifat konseptual maupun yang sifatnya teknis. Tulisan ini tidak bermaksud menjawabnya namun berupaya mencari peluang solusi yang mungkin dapat dipecahkan dengan basis pengalaman dan pengetahuan baik teoritik atau praktik.

\section{Hukum HAM Internasional dan Hukum Nasional}

Acuan utama dalam hukum hak asasi manusia internasional mengenai definisi korban adalah Declaration of Basic Principle of Justice for Victim and Abuse of Power, adopted by General Assembly Resolution 40/ 34 of 29 November 1985/Deklarasi Prinsip-Prinsip Dasar Keadilan Bagi Korban Kejahatan dan Penyalahgunaan Kekuasaan (selanjutnya disebut deklarasi korban). Acuan utama lainnya adalah yang terdapat dalam Aturan Hukum Acara dan Pembuktian pada Mahkamah Pidana Internasional (ICC) yang mana rumusannya menguatkan konsep mengenai korban dalam konteks pelanggaran hak asasi manusia yang berat. Menyangkut pelanggaran hak asasi manusia yang berat dalam hukum nasional, definisi mengenai korban merujuk pada PP Nomor 2 tahun 2002 tentang Tata Cara Perlindungan terhadap Korban dan Saksi dalam Pelanggaran Hak Asasi Manusia yang Berat dan Undang-undang Nomor 13 tahun 2006 tentang perlindungan

Saksi dan Korban. Keempat rujukan definisi dalam hukum internasional dan nasional disajikan pada tabel di bawah ini : 
Tabel Persandingan Definisi Korban ${ }^{1}$

\begin{tabular}{|c|c|c|c|}
\hline $\begin{array}{l}\text { ut UU } \\
\text { ungan } \\
\text { Korban }\end{array}$ & $\begin{array}{c}\text { Menurut PP } \\
\text { No } 2 \text { tahun } \\
2002\end{array}$ & $\begin{array}{c}\text { Deklarasi } \\
\text { Prinsip-prinsip } \\
\text { Dasar Keadilan } \\
\text { bagi Korban }\end{array}$ & $\begin{array}{l}\text { Pengadilan } \\
\text { Pidana } \\
\text { Internasional }^{3}\end{array}$ \\
\hline 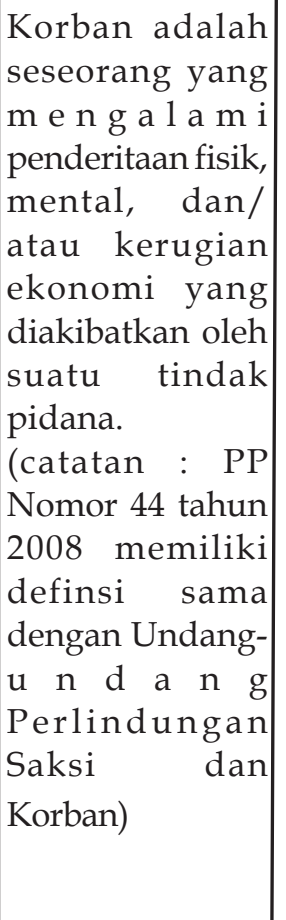 & $\begin{array}{l}\text { Korban adalah } \\
\text { o } \mathrm{r} \text { a } \mathrm{n} \\
\text { perseorangan } \\
\text { atau kelompok } \\
\text { orang yang } \\
\text { mengala mi } \\
\text { penderitaan } \\
\text { sebagai akibat } \\
\text { pelanggaran } \\
\text { hak asasi } \\
\text { manusia yang } \\
\text { berat yang } \\
\text { memerlukan } \\
\text { perlindungan } \\
\text { fisikdanmental } \\
\text { dari ancaman, } \\
\text { ga } \mathrm{n} g \mathrm{~g} \text { a } \mathrm{n}, \\
\text { teror, dan } \\
\text { kekerasan dari } \\
\mathrm{p} \mathrm{i} \mathrm{h} \text { a } \mathrm{k} \\
\text { manapun. }\end{array}$ & $\begin{array}{l}\text { Korban adalah } \\
\text { orang orang yang, } \\
\text { secara individu } \\
\text { atau kolektif, telah } \\
\mathrm{m} \text { e n d e r i t a } \\
\text { k e r u g i a n, } \\
\text { termasuk luka fisik } \\
\text { atau mental, } \\
\text { p e n d e r i t a a n } \\
\text { e m o s i o n a } 1, \\
\text { kerugian ekonomi } \\
\text { atau perusakan } \\
\text { yang substansial } \\
\text { atas hak dasarnya, } \\
\text { lewat tindakan } \\
\text { atau pembiaran } \\
\text { yang bertentangan } \\
\text { dengan hukum } \\
\text { pidana yang } \\
\text { berlaku di negara- } \\
\text { negara anggota, }\end{array}$ & $\begin{array}{l}\text { (a) korban berartiorang } \\
\text { - orang yang telah } \\
\text { mengalami derita } \\
\text { atau kerugian } \\
\text { sebagai akibat } \\
\text { dilakukannya } \\
\text { berbagai kejahatan } \\
\text { yang termasuk } \\
\text { dalam jurisdiksi } \\
\text { Mahkamah } \\
\text { (b) korban bisa } \\
\text { m e n a k u } \\
\text { organisasi - } \\
\text { organisasi atau } \\
\text { lembaga- lembaga } \\
\text { yang benar - benar } \\
\text { tertimpa kerugian } \\
\text { langsungatas harta } \\
\text { milik mereka yang } \\
\text { dibaktikan bagi } \\
\text { kepentingan }\end{array}$ \\
\hline
\end{tabular}

${ }^{1}$ Lihat Syahrial \& Melly, Pemberian Bantuan dalam Undang-Undang tentang Perlindungan Saksi dan Korban, ICW-ICJR \& Koalisi Perlindungan Saksi, 2007 hal 11-13.

${ }^{2}$ Lihat teks asli: Declaration of Basic Principles of Justice for Victims of Crime and Abuse of Power (adopted by General Assembly resolution 40/34 of November 1985), "Victims means persons who, individually or collectively, have suffered harm, including physical or mental injury, emotional suffering, economic loss or substantial impairment of their fundamental rights, through acts or ommisons tat are in violation of criminal laws operative within Members States, including thise laws proscribing criminal abuse of power."

${ }^{3}$ Lihat teks asli: Rules of Procedure and Evidence Rule 85 Definiton Of Victims For the purposes of the Statute and the Rules of Procedure and Evidence:

(a) Victims. means natural persons who have suffered harm as a result of the commission of any crime within the jurisdiction of the Court;

(b) Victims may include organizations or institutions that have sustained direct harm to any of their property which is dedicated to religion, education, art or science or charitable purposes, and to their historic monuments, hospitals and other places and objects for humanitarian purposes. 


\begin{tabular}{|l|l|l|l|}
\hline & $\begin{array}{l}\text { termasuk hukum } \\
\text { yang melarang } \\
\text { penyalahgunaan } \\
\text { kekuasaan yang } \\
\text { bisa dikenai } \\
\text { pidana }\end{array}$ & $\begin{array}{l}\text { agama, pendidikan, } \\
\text { sengetahuan atau } \\
\text { untuk tujuan - tujuan } \\
\text { karitatif dan atas } \\
\text { monumen-monumen } \\
\text { sejarah mereka, rumah } \\
\text { sakit dan tempat } \\
\text { tempat serta objek- } \\
\text { objek lainnya yang } \\
\text { diabdikan bagi } \\
\text { kepentingan atau misi } \\
\text { kemanusiaan. }\end{array}$ \\
\hline
\end{tabular}

Unsur-unsur pokok yang dibangun dalam definisi korban meliputi dua hal penting yakni : pertama, subjek korban yang mencakup perorangan atau kelompok, dan kedua, aspek kerugian dan penderitaan yang diakibatkan oleh adanya suatu tindakan yang melawan hukum. Jika ditelusuri, setelah lahirnya undang-undang Perlindungan Saksi dan Korban, rumusan definisi mengenai korban bergeser ke arah individualisasi korban. Jika disandingkan dengan PP No. 2 tahun 2002 dan UU Perlindungan Saksi dan Korban (serta PP No.44 tahun 2008 tentang Pemberian Kompensasi, Restitusi dan Korban kepada Saksi dan Korban), maka undang-undang ini tidak menyebutkan aspek karakter korban yang sifatnya kolektif. Padahal karakter korban pada pelanggaran hak asasi manusia, korban umumnya merupakan korban yang sifatnya adalah kelompok/ kolektif.

Norma yang dirumuskan dalam undang-undang, dikonstruksikan dalam pengertian secara individual, tidak meliputi kelompok sebagaimana dicakup pada definisi dalam PP No 2 tahun 2002 atau Declaration of Basic Principles of Justice for Victims of Crime and Abuse of Power (adopted by General Assembly resolution 40/ 34 of November 1985) serta Aturan 85 Pengadilan Pidana Internasional (ICC-International Criminal Court). Dalam konteks tugas dan kewenangan LPSK problem rumusan yuridis ini, menjadi pekerjaan yang harus ditangani secara serius demi memberikan layanan perlindungan yang terbaik bagi korban. Keterbatasan cakupan dari subjek korban ini tentunya akan memberikan implikasi khususnya bagi pengembangan pranata perlindungan dan bantuan yang akan diberikan LPSK kepada korban. 


\section{Hak-Hak Korban Pelanggaran Hak Asasi Manusia yang Berat}

Dalam deklarasi korban dinyatakan beberapa hak pokok korban yang harus dijamin dan dilindungi oleh negara yakni: Pertama, hak korban atas tersedianya mekanisme keadilan dan memperoleh ganti rugi dengan segera (baik berupa kompensasi maupun restitusi); Kedua, hak atas informasi mengenai hak-haknya dalam mengupayakan ganti rugi dan memperoleh informasi kemajuan proses hukum yang berjalan termasuk ganti kerugian; Ketiga, hak untuk menyatakan pandangan dan memberikan pendapat; Keempat; hak atas tersedianya bantuan selama proses hukuman dijalankan; Kelima, hak atas perlindungan dari gangguan/intimidasi/ tindakan balasan dari pelaku, perlindungan kebebasan pribadi dan keselamatan baik pribadi maupun keluarganya, dan Keenam, hak atas mekanisme/ proses keadilan yang cepat dan sederhana/ tidak adanya penundaan.

Sementara itu dalam Statuta Roma dan aturan mengenai hukum dan pembuktian, sebagai instrumen hukum hak asasi manusia internasional pokok yang terkait erat pelanggaran hak asasi manusia yang berat memberikan perhatian khusus atas posisi korban dalam proses berjalannya peradilan. Hal tersebut diatur dalam beberapa pasal yang mengatur mengenai hak-hak korban selama proses peradilan berlangung. Yaitu : Pertama, hak atas perlindungan bagi korban selama proses peradilan berlangsung (pasal 57 yang mengatur perlindungan pada tahap pre trial maupun Pasal 68 yang berisi hak-hak korban selama proses persidangan, seperti partisipasi korban, mekanisme perlindungan dalam tahapan pembuktian untuk memberikan keterangan secara in camera maupun pengajuan bukti dengan sarana elektronika). Kedua, hak atas jaminan perlindungan baik dalam konteks finansial maupun fasilitas lainnya bagi korban kejahatan dan keluarganya (Pasal 79 mengatur mengenai pembentukan Trust Fund untuk menjamin hak-hak korban kejahatan dan keluarganya).

Selain dua dokumen di atas, dalam ranah hukum hak asasi manusia internasional dikenal pula prinsip-prinsip van Boven dan prinsip-prinsip Joinet sebagai dua acuan pokok yang dirumuskan melalui studi mendalam oleh Pelapor Khusus Sub Komisi Hak Asasi Manusia PBB dan ahli independen. Berdasarkan beberapa kaidah hukum Internasional bahwa setiap pelanggaran terhadap hak asasi manusia akan menimbulkan hak atas pemulihan. Yang dimaksud pemulihan menurut Van Boven adalah 
segala jenis ganti rugi (redress) yang bersifat material maupun non material bagi para korban pelanggaran hak - hak asasi manusia oleh karena itu hak kompensasi, restitusi dan rehabilitasi mencakup aspek - aspek tertentu dari pemulihan. Boven mengusulkan enam prinsip dasar yang harus dipenuhi oleh negara yang akan merumuskan kebijakan untuk pemenuhan hak-hak korban, yakni : Pertama, pemulihan dapat dituntut secara individual maupun kolektif. Kedua, negara berkewajiban menerapkan langkah-langkah khusus yang memungkinkan dilakukannya langkah-langkah pemulihan yang efektif secara penuh. Pemulihan harus seimbang dengan beratnya pelanggaran dan kerusakan-kerusakan yang diakibatkannya, yang mencakup pula restitusi, kompensasi, rehabilitasi, kepuasan, dan jaminan agar kejadian serupa tidak terulang. Ketiga, setiap negara harus mengumumkan melalui mekanisme publik maupun lembaga swasta baik di dalam maupun di luar negeri tentang tersedianya prosedurprosedur pemulihan. Keempat, ketentuan-ketentuan pembatasan tidak boleh diterapkan selama masa dimana tidak ada penyelesaian efektif atas pelanggaran hak asasi manusia dan pelanggaran hukum humaniter. Kelima, setiap negara harus memungkinkan tersedianya secara cepat seluruh informasi yang berkenaan dengan persyaratan-persyaratan tuntutan pemulihan. Keenam, keputusan-keputusan menyangkut pemulihan atas korban pelanggaran hak asasi manusia dan pelanggaran hukum humaniter harus dilaksanakan melalaui cara yang cermat dan cepat. ${ }^{4}$

Sedangkan dalam prinsip Joinet, secara garis besar merupakan usaha perlindungan dan pemajuan hak asasi manusia melalui langkah-langkah untuk menghapus impunitas dengan mengadopsi prinsip-prinsip dasar hak asasi manusia universal untuk diterapkan hingga pada upaya-upaya dalam bekerjanya mekanisme hukum domestik. Dalam studi tersebut, dipaparkan dalam empat point penting yakni: hak untuk mengetahui, hak atas keadilan, hak atas reparasi, dan jaminan ketidakberulangan. Salah satu prinsip hak atas keadilan yang cukup penting untuk diangkat adalah ketentuan mengenai prinsip pembatasan yang dibenarkan oleh keinginan untuk memerangi impunitas, mengenai ketentuan amnesti dalam pelanggran hak asasi manusia yang berat. Jelas dalam prinsip tersebut menyatakan bahwa amnesti tidak dapat diberikan kepada pelaku pelanggaran sebelum korban mendapatkan keadilan melalui pengadilan

\footnotetext{
${ }^{4}$ Lihat Theo Van Boven, Mereka yang Menjadi Korban, Hak Korban atas Restitusi,
} Kompensasi, dan Rehabilitasi. Pengantar Buku; Ifdhal Kasim hal. xxi-xxii, ELSAM, 2002. 
yang efektif. Amnesti tidak boleh memiliki pengaruh hukum apapun terhadap proses peradilan yang diajukan oleh korban terkait dengan reparasi. ${ }^{5}$

Sistem peradilan pidana dapat mengembangkan upaya-upaya pemulihan bagi korban pelanggaran hak asasi manusia melalui beberapa metode yang secara garis besar dibedakan menjadi dua, yakni: monetary remedies dan non-monetary remedies. ${ }^{6}$ Monetary remedies merupakan pemulihan yang mendayagunakan nilai materi dalam wujud uang atau fisik untuk mereparasi kerusakan/kerugian yang diakibatkan oleh adanya pelanggaran hak asasi manusia. Sedangkan Non-Monetary Remedies adalah upaya pemulihan bagi korban yang lebih mendasarkan pada perbaikan atas kerusakan/kerugian yang ditimbulkan dengan langkahlangkah tertentu yang tidak dapat dipadankan dengan nilai material tertentu (seperti: permintaan maaf dari pelaku/negara, jaminan ketidakberulangan, rehabilitasi, truth telling, hukuman bagi pelaku, atau pernyataan melalui putusan hakim (declaratory judgements).

Pada ranah hukum nasional, sejak diberlakukannya undang-undang tentang Perlindungan Saksi dan Korban dan PP Nomor 44 tahun 2008, dalam pelaksanaan perlindungan bagi korban pelanggaran hak asasi manusia yang berat praktis mengacu pada dua peraturan perundangundangan tersebut. Meskipun sepanjang tidak bertentangan dengan kedua peraturan perundang-undangan tersebut undang-undang dan peraturan pemerintah lainnya masih diberlakukan. ${ }^{7}$ Dalam undang-undang tersebut hak-hak korban tidak dibedakan secara khusus dari hak-hak yang dimiliki saksi. Artinya undang-undang telah mengakomodasi hak atas keadilan yang layak bagi korban karena jaminan perlindungan bagi korban telah didapatkan sejak proses penyelidikan dilakukan. Dalam undang-undang Perlindungan Saksi dan Korban, korban pelanggaran hak asasi manusia memiliki dua hak eksklusif yang diberikan oleh undang-undang yakni hak atas kompensasi dan pemberian bantuan, selain tentunya terdapat

${ }^{5}$ Lihat,Kontras, Menolak Impunitas, Serangkaian Prinsip Perlindungan dan Pemajuan Hak Asasi Manusia. Prinsip-Prinsip Hak Korban. Kontras, 2005. hlm. 128.

${ }^{6}$ Lihat Dinah Shelton, Remedies in International Human Rights Law, Oxford University, 1999.

${ }^{7}$ Ketentuan dalam Undang-Undang Nomor 26 tahun 2000, Peraturan Pemerintah Nomor 2 Tahun 2002 tentang Tata Cara Perlindungan terhadap Korban dan Saksi dalam Pelanggaran Hak Asasi Manusia yang Berat, dan Peraturan Pemerintah Nomor 3 tahun 2002 tentang Kompensasi, Restitusi, dan Rehabilitasi terhadap Korban Pelanggaran Hak Asasi Manusia yang Berat. 
pula hak untuk mengajukan restitusi kepada pelaku kejahatan. ${ }^{8}$ Dalam pandangan penulis, mengenai rumusan dari definisi kompensasi yang terdapat pada PP Nomor 44 tahun 2008 terdapat kesalahan konseptual yang sifatnya fundamental. Rumusan pengertian kompensasi dalam PP tersebut adalah ganti kerugian yang diberikan oleh negara karena pelaku tidak mampu memberikan ganti kerugian sepenuhnya yang menjadi tanggung jawabnya.

Dengan rumusan tersebut, maka kompensasi baru akan dapat dijalankan dengan menggantungkan ada tidaknya pelaku dan/atau mampu atau tidaknya pelaku untuk memberikan ganti rugi. Tentunya ini tidak sebangun dengan konsep dan prinsip-prinsip hukum hak asasi manusia, yang memberikan kewajiban kepada negara untuk memberikan perlindungan dan jaminan kepada korban secara maskimal dengan mengambil langkah-langkah yang tepat, cermat, cepat, dan memberikan kepuasan bagi korban pelanggaran hak asasi manusia yang berat. Tentunya hal ini akan menjadi catatan penting bagi penulis dan bagi semua peserta diskusi.

Pasal 5, Pasal 6, dan Pasal 7 undang-undang tentang Perlindungan Saksi dan Korban menjadi rujukan mengenai hak-hak, bentuk-bentuk perlindungan, dan bentuk bantuan yang dijamin oleh undang-undang. Dalam Pasal 5, terdapat 13 (tiga belas) hak saksi dan atau korban yang dalam konteks pemberian perlindungan akan diberikan oleh LPSK. Dalam Pasal 5 tersebut, undang-undang tentang Perlindungan Saksi dan Korban menyebutkan bahwa perlindungan utama yang diperlukan adalah perlindungan atas keamanan pribadi, keluarga, dan harta benda, serta bebas dari ancaman yang berkaitan dengan kesaksiannya dalam proses perkara yang berjalan. Untuk lebih jelasnya apa saja hak-hak saksi dan atau korban yang dapat diberikan oleh LPSK dapat dilihat dalam tabel 1. Selain Pasal 5, korban juga memiliki hak atas kompensasi dan hak atas restitusi sebagaimana diatur pada Pasal 7 undang-undang tentang

${ }^{8}$ Pembahasan lebih detail mengenai kompensasi dan restitusi disarankan untuk melihat kajian dari Wahyu Wagiman \& Zainal Abidin, Praktik Kompensasi dan Restitusi di Indonesia, sebuah Kajian Awal, ICW-ICJR, dan Koalisi Perlindungan Saksi, 2007. Sedangkan pembahasan mengenai pemberian bantuan dapat dilihat, Syahrial MW\& Melly,Pemberian Bantuan dalam Undang-undang tentang Perlindungan Saksi dan Korban, ICW-ICJR \& Koalisi Perlindungan Saksi, 2007 serta Naskah Akademis dan RPP Pemberian Kompensasi dan Restitusi serta Bantuan bagi Saksi dan Korban Usul Inisiatif Masyarakat, ICW - ICJR- Koalisi Perlindungan Saksi, 2008. 
Perlindungan Saksi. Menurut undang-undang tentang Perlindungan Saksi dan Korban, dalam Pasal 6 khusus terhadap korban pelanggaran hak asasi manusia berhak pula atas bantuan medis dan bantuan rehabilitasi psiko-sosial. $^{9}$

Hak-hak saksi dan korban yang dimuat pada Pasal 5

Undang-undang tentang Perlindungan Saksi dan Korban

\begin{tabular}{|c|c|}
\hline $\begin{array}{c}\text { Bunyi Pasal mengenai hak-hak } \\
\text { yang dijamin oleh UU } \\
\text { Perlindungan Saksi dan Korban }\end{array}$ & $\begin{array}{l}\text { Penjelasan Undang-undang tentang } \\
\text { Perlindungan Saksi dan Korban }\end{array}$ \\
\hline $\begin{array}{l}\text { Huruf a Memperoleh perlindungan } \\
\text { atas keamanan pribadi, keluarga, dan } \\
\text { harta bendanya, serta bebas dari } \\
\text { ancaman yang berkenaan dengan } \\
\text { kesaksian yang akan, sedang, atau } \\
\text { telah diberikannya; }\end{array}$ & $\begin{array}{l}\text { Perlindungan semacam ini merupakan } \\
\text { perlindungan utama yang diperlukan Saksi } \\
\text { dan Korban. Apabila perlu, Saksi dan } \\
\text { Korban harus ditempatkan dalam suatu } \\
\text { lokasi yang dirahasiakan dari siapa pun } \\
\text { untuk menjamin agar Saksi dan Korban } \\
\text { aman }\end{array}$ \\
\hline $\begin{array}{l}\text { Huruf b ikut serta dalam proses } \\
\text { memilih dan menentukan bentuk } \\
\text { perlindungan dan dukungan } \\
\text { keamanan; }\end{array}$ & Cukup jelas. \\
\hline $\begin{array}{l}\text { Huruf c memberikan keterangan } \\
\text { tanpa tekanan; }\end{array}$ & Cukup jelas. \\
\hline Huruf d Mendapat penerjemah; & $\begin{array}{l}\text { Hak ini diberikan kepada Saksi dan } \\
\text { Korban yang tidak lancar berbahasa } \\
\text { Indonesia untuk memperLancar } \\
\text { persidangan. }\end{array}$ \\
\hline $\begin{array}{l}\text { Huruf e Bebas dari pertanyaan } \\
\text { yang menjerat; }\end{array}$ & Cukup jelas. \\
\hline $\begin{array}{l}\text { Huruf f mendapatkan informasi } \\
\text { mengenai perkembangan kasus; } \\
\text { sampai batas waktu perlindungan } \\
\text { berakhir }\end{array}$ & $\begin{array}{l}\text { Seringkali Saksi dan Korban hanya } \\
\text { berperan dalam pemberian kesaksian di } \\
\text { pengadilan, tetapi Saksi dan Korban tidak } \\
\text { mengetahui perkembangan kasus yang } \\
\text { bersangkutan. Oleh karma itu, sudah } \\
\text { seharusnya informasi mengenai } \\
\text { perkembangan kasus diberikan kepada } \\
\text { Saksi dan Korban. }\end{array}$ \\
\hline
\end{tabular}

${ }^{9}$ Pembahasan mengenai hak-hak saksi dan korban dalam undang-undang Perlindungan Saksi dan Korban ini disarikan dari; Syahrial \& Melly, Pemberian Bantuan dalam Undang-undang tentang Perlindungan Saksi dan Korban, ICW-ICJR \& Koalisi Perlindungan Saksi, 2007 


\begin{tabular}{|c|c|}
\hline $\begin{array}{c}\text { Bunyi Pasal mengenai hak-hak } \\
\text { yang dijamin oleh UU } \\
\text { Perlindungan Saksi dan Korban }\end{array}$ & $\begin{array}{l}\text { Penjelasan Undang-undang tentang } \\
\text { Perlindungan Saksi dan Korban }\end{array}$ \\
\hline $\begin{array}{l}\text { Huruf g mendapatkan informasi } \\
\text { mengenai putusan pengadilan; }\end{array}$ & $\begin{array}{l}\text { Informasi ini penting untuk diketahui Saksi } \\
\text { dan Korban sebagai tanda penghargaan } \\
\text { atas kesediaan Saksi dan Korban dalam } \\
\text { proses peradilan tersebut. }\end{array}$ \\
\hline $\begin{array}{l}\text { Huruf h mengetahui dalam hal } \\
\text { terpidana dibebaskan; }\end{array}$ & $\begin{array}{l}\text { Ketakutan Saksi dan Korban akan adanya } \\
\text { balas dendam dari terdakwa cukup } \\
\text { beralasan dan berhak diberi tahu apabila } \\
\text { seorang terpidana yang dihukum penjara } \\
\text { akan dibebaskan. }\end{array}$ \\
\hline Huruf i mendapat identitas baru; & $\begin{array}{l}\text { Dalam berbagai kasus, terutama yang } \\
\text { menyangkut kejahatan terorganisasi, } \\
\text { Saksi dan Korban dapat terancam } \\
\text { walaupun terdakwa sudah dihukum. } \\
\text { Dalam kasus-kasus tertentu, Saksi dan } \\
\text { Korban dapat diberi identitas baru. }\end{array}$ \\
\hline $\begin{array}{l}\text { Huruf j mendapatkan tempat } \\
\text { kediaman baru; }\end{array}$ & $\begin{array}{l}\text { Apabila keamanan Saksi dan Korban } \\
\text { sudah sangat mengkhawatirkan, } \\
\text { pemberian tempat baru pada Saksi dan } \\
\text { Korban harus dipertimbangkan agar Saksi } \\
\text { dan Korban dapat meneruskan } \\
\text { kehidupannya tanpa ketakutan. Yang } \\
\text { dimaksud dengan "tempat kediaman } \\
\text { baru" adalah tempat tertentu yang bersifat } \\
\text { sementara dan dianggap aman. }\end{array}$ \\
\hline $\begin{array}{l}\text { Huruf k memperoleh penggantian } \\
\text { biaya transportasi sesuai dengan } \\
\text { kebutuhan; }\end{array}$ & $\begin{array}{l}\text { Saksi dan Korban yang tidak mampu } \\
\text { membiayai dirinya untuk mendatangi } \\
\text { lokasi, perlu mendapat bantuan biaya dari } \\
\text { negara. }\end{array}$ \\
\hline Huruf 1 Mendapat nasihat hukum; & $\begin{array}{l}\text { Yang dimaksud dengan "nasihat hukum" } \\
\text { adalah nasihat hukum yang dibutuhkan } \\
\text { oleh Saksi dan Korban apabila diperlukan. }\end{array}$ \\
\hline $\begin{array}{l}\text { Huruf m memperoleh bantuan biaya } \\
\text { hidup sementara }\end{array}$ & $\begin{array}{l}\text { Yang dimaksud dengan "biaya hidup } \\
\text { sementara" adalah biaya hidup yang } \\
\text { sesuai dengan situasi yang dihadapi pada } \\
\text { waktu itu, misalnya biaya untuk makan } \\
\text { sehari-hari. }\end{array}$ \\
\hline
\end{tabular}




\section{Peran LPSK dalam Perlindungan Korban Pelanggaran Hak Asasi Manusia $^{10}$}

Uraian mengenai hak-hak korban di atas, menurunkan beberapa kategori tindakan atau langkah-langkah yang akan menjadi tugas dan kewenangan LPSK, yaitu:

Pertama, bentuk jaminan perlindungan fisik yang diberikan oleh LPSK yaitu: Perlindungan atas keamanan pribadi, keluarga, dan harta benda (Pasal 5 ayat (1) a); Perlindungan dari ancaman (Pasal 5 ayat (1) a); Mendapatkan identitas baru (Pasal 5 ayat (1) i); dan Mendapatkan tempat kediaman baru (Pasal 5 ayat (1) j).

Kedua, bentuk partisipasi saksi/korban dalam program perlindungan LPSK yaitu: saksi dan atau korban memiliki hak untuk ikut serta dalam proses memilih dan menentukan bentuk perlindungan dan dukungan keamanan (Pasal 5 ayat (1) b).

Ketiga, bentuk jaminan yang berkaitan dengan administrasi peradilan pada semua tahapan proses hukum yang dijalankan yaitu: Saksi dan atau korban memberikan keterangan tanpa tekanan dalam setiap tahapan proses hukum yang berlangsung (Pasal 5 ayat (1)c); Saksi dan atau korban akan didampingi penerjemah, dalam hal keterbatasan atau terdapat hambatan berbahasa (Pasal 5 ayat (1)d); Saksi dan atau korban terbebas dari pertanyaan yang menjerat (Pasal 5 ayat (1)e); Saksi dan atau korban mendapatkan informasi mengenai perkembangan kasus hingga batas waktu perlindungan berakhir (Pasal 5 ayat (1) f); Saksi dan atau korban akan diberitahukan dalam hal terpidana dibebaskan (Pasal 5 ayat (1)h); Saksi dan atau korban berhak didampingi oleh penasihat hukum untuk mendapatkan nasihat-nasihat hukum (Pasal 5 ayat (1) 1).

Keempat, bentuk pemberian dukungan pembiayaan dan layanan medis/psiko - sosial yaitu: biaya transportasi (Pasal 5 ayat (1) k); Biaya hidup sementara (Pasal 5 ayat (1)m); bantuan medis (Pasal 6 a); dan bantuan rehabilitasi psiko-sosial (Pasal 6 b).

Kelima, bentuk reparasi (pemulihan) bagi korban pelanggaran hak asasi manusia yang berat yang dapat diajukan oleh LPSK yaitu: Pengajuan kompensasi bagi korban (Pasal 7 ayat (1) a) dan Pengajuan restitusi bagi korban (Pasal 7 ayat (1) b)

10 Uraian dalam bagian ini disarikan dari sub bab mengenai tugas dan fungsi LPSK menurut Undang-undang Perlindungan Saksi dan Korban, dalam buku Syahrial \& Melly, Pemberian Bantuan ..., Loc., Cit 
Kelima, bentuk tindakan dan layanan yang diberikan oleh LPSK itulah yang menggambarkan tugas dan fungsi LPSK sebagaimana telah disebut dalam UU PSK, tepatnya Pasal 1 angka 3 dan Pasal 12.

Pasal 1 angka 3

Lembaga Perlindungan Saksi dan Korban, yang selanjutnya disingkat LPSK, adalah lembaga yang bertugas dan berwenang untuk memberikan perlindungan dan hak-hak lain kepada saksi dan/atau korban sebagaiman diatur dalam Undang-Undang ini.

Pasal 12

LPSK bertanggung jawab untuk menangani pemberian perlindungan dan bantuan pada saksi dan korban berdasarkan tugas dan kewenangan sebagaimana diatur dalam undang-undang ini.

Dalam Pasal 10, LPSK juga mendapatkan mandat dari UU PSK untuk memastikan perlindungan kepada saksi dan korban mengenai jaminan dari undang-undang, bahwa saksi dan korban tidak dapat dituntut secara hukum baik pidana maupun perdata sehubungan dengan laporan dan kesaksiannya.

\section{Pasal 10}

(1) Saksi, Korban, dan Pelapor tidak dapat dituntut secara hukum baik pidana maupun perdata atas laporan, kesaksian yang akan, sedang, atau telah diberikannya.

(2) Seorang saksi yang juga tersangka dalam kasus yang sama tidak dapat dibebaskan dari tuntutan pidana apabila ia ternyata terbukti secara sah dan menyakinkan bersalah, tetapi kesaksiannya dapat dijadikan pertimbangan hakim dalam meringankan pidana yang akan dijatuhkan.

(3) Ketentuan sebagaimana dimaksud pada ayat (1) tidak berlaku terhadap saksi, korban dan pelapor yang memberikan keterangan tidak pada itikad baik.

Pasal 10 juga memberikan tugas bagi LPSK untuk memastikan keringanan hukuman bagi tersangka yang juga dijadikan saksi oleh LPSK. Meskipun kewenangan keringanan hukuman mutlak merupakan otoritas hakim, Pasal 10 ayat (2) ini jelas mengaitkan tugas dan fungsi LPSK dalam proses persidangan untuk memastikan keringanan bagi seorang saksi yang juga tersangka ikut serta dalam program perlindungan saksi LPSK. ${ }^{11}$

\footnotetext{
${ }^{11}$ Pasal 10 ayat (2) UU PSK, prinsipnya mirip dengan mekanisme plea bargaining
} (mengenai pengertian plea bargaining adalah: The process whereby the accused and 
Kategori Tindakan dan Layanaan yang diberikan LPSK

\begin{tabular}{|c|c|}
\hline $\begin{array}{l}\text { Kategori Tindakan } \\
\text { dan Layanan }\end{array}$ & $\begin{array}{l}\text { Bentuk Perlindungan dan Bantuan serta } \\
\text { Rujukan Pasalnya }\end{array}$ \\
\hline 1. Perlindungan fisik & $\begin{array}{l}\text { A. Perlindungan atas keamanan pribadi, } \\
\text { keluarga, dan harta benda (Pasal } 5 \text { ayat (1) a) } \\
\text { B. Perlindungan dari ancaman (Pasal } 5 \text { ayat (1) } \\
\text { a) } \\
\text { C. Mendapatkan identitas baru (Pasal } 5 \text { ayat } \\
\text { (1) i) } \\
\text { D. Mendapatkan tempat kediaman baru (Pasal } \\
5 \text { ayat (1) j). }\end{array}$ \\
\hline $\begin{array}{l}\text { 2. J a m i n a n } \\
\text { partisipasi saksi/ } \\
\text { korban dalam pro- } \\
\text { gram perlindung- } \\
\text { an LPSK }\end{array}$ & $\begin{array}{l}\text { Saksi dan atau korban memiliki hak untuk ikut } \\
\text { serta dalam proses memilih dan menentukan } \\
\text { bentuk perlindungan dan dukungan keamanan } \\
\text { (Pasal } 5 \text { ayat }(1) \text { b) }\end{array}$ \\
\hline $\begin{array}{l}\text { 3. A d ministrasi } \\
\text { peradilan }\end{array}$ & $\begin{array}{l}\text { A. Saksi dan atau korban memberikan } \\
\text { keterangan tanpa tekanan dalam setiap } \\
\text { tahapan proses hukum yang berlangsung } \\
\text { (Pasal } 5 \text { ayat (1)c) } \\
\text { B. Saksi dan atau korban akan didampingi } \\
\text { penerjemah, dalam hal keterbatasan atau } \\
\text { terdapat hamabtan berbahasa (Pasal } 5 \text { ayat } \\
\text { (1)d) } \\
\text { C. Saksi dan atau korban terbebas dari } \\
\text { pertanyaan yang menjerat (Pasal } 5 \text { ayat (1)e) } \\
\text { D Saksi dan atau korban mendapatkan } \\
\text { informasi mengenai perkembangan kasus } \\
\text { hingga batas waktu perlindungan berakhir } \\
\text { (Pasal } 5 \text { ayat (1) f) }\end{array}$ \\
\hline
\end{tabular}

the prosecutor in a criminal case work out a mutually satisfactory disposition of the case subject t court approval. It usulalyl involves the defendant's pleading guilty to a lesser offense or to only one or some of the counts of a multi-count indictment in return for a lighter sentence than that possible for the graver charge. Lihat Black's Law Dictionary). LPSK menurut pasal ini berperan untuk memastikan adanya keringanan hukuman bagi tersangka yang juga menjadi saksi. Artinya LPSK harus melakukan langkah-langkah negosiasi dengan penegak hukum lainnya, khususnya hakim. 


\begin{tabular}{|c|c|c|}
\hline $\begin{array}{l}\text { Kategori Tindakan } \\
\text { dan Layanan }\end{array}$ & & $\begin{array}{c}\text { Bentuk Perlindungan dan Bantuan serta } \\
\text { Rujukan Pasalnya }\end{array}$ \\
\hline & & $\begin{array}{l}\text { Saksi dan atau korban akan diberitahukan } \\
\text { dalam hal terpidana dibebaskan (Pasal } 5 \\
\text { ayat (1)h) } \\
\text { Saksi dan atau korban berhak didampingi } \\
\text { oleh penasihat hukum untuk mendapatkan } \\
\text { nasihat-nasihat hukum (Pasal } 5 \text { ayat (1) 1) }\end{array}$ \\
\hline $\begin{array}{l}\text { 4. D u k u n g a } \\
\text { pembiayaan dan } \\
\text { layanan medis / } \\
\text { psiko - social }\end{array}$ & $\begin{array}{l}\text { A } \\
\text { B } \\
\text { C } \\
\text { D }\end{array}$ & $\begin{array}{l}\text { biaya transportasi (Pasal } 5 \text { ayat }(1) \mathrm{k} \text { ) } \\
\text { biaya hidup sementara (Pasal } 5 \text { ayat }(1) \mathrm{m}) \\
\text { bantuan medis (Pasal } 6 \text { a) } \\
\text { bantuan rehabilitasi psiko-sosial (Pasal } 6 \text { b) }\end{array}$ \\
\hline $\begin{array}{l}\text { Bentuk reparasi } \\
\text { (pemulihan) }\end{array}$ & $\mathrm{A}$ & $\begin{array}{l}\text { Pengajuan kompensasi bagi korban (Pasal } \\
7 \text { ayat (1) a) } \\
\text { Pengajuan restitusi bagi korban (Pasal } 7 \text { ayat } \\
\text { (1) b) }\end{array}$ \\
\hline
\end{tabular}

\section{Penutup}

Berdasarkan uraian di atas dapat disimpulkan bahwa, kelemahankelemahan konseptual dalam rumusan substansi peraturan perundangundangan yang mengatur mengenai korban pelanggaran hak asasi manusia yang berat masih terdapat dalam hukum positif kita sekarang ini. Aspek substansi tersebut dikhawatirkan akan berimplikasi buruk bagi pelaksanaan perlindungan hak-hak korban pelanggaran hak asasi manusia yang berat, mengingat aspek proseduralnya sudah barang tentu sedikit banyak akan mengacu pada hukum materiilnya. Kondisi ini tentunya menjadi tantangan yang diharapkan memacu semua pihak untuk dapat memperbaiki dan memberikan sumbangsih terbaik dalam upaya perlindungan, pemajuan hak asasi manusia, serta penegakan hukum dan keadilan bagi korban.

\section{Daftar Bacaan}

Dinah Shelton, Remedies in International Human Rights Law, Oxford University, 1999.

ELSAM, Mahkamah Pidana Internasional, Statuta Roma, Hukum Acara, dan Unsur-unsur Kejahatan, ELSAM, 2007.

KONTRAS, Menolak Impunitas, Serangakian Prinsip perlindungandan pemajuan Hak asasi Manusia. Prinsip-Prinsip Hak Korban, KONTRAS, 2005. 
Syahrial Martanto Wiryawan \& Melly Setyowati, Pemberian Bantuan dalam Undang-undang tentang Perlindungan Saksi dan Korban, ICW-ICJR \& Koalisi Perlindungan Saksi, 2007

Theo Van Boven, Mereka yang Menjadi Korban, Hak Korban atas Restitusi, Kompensasi, dan Rehabilitasi, ELSAM, 2002.

Tim Kerja RPP Pemberian Kompensasi, Restitusi, dan Bantuan, Naskah Akademis dan RPP Pemberian Kompensasi dan Restitusi serta Bantuan bagi Saksi dan Korban Usul Inisiatif Masyarakat, ICW - ICJR- Koalisi Perlindungan Saksi, 2008.

Wahyu Wagiman\&Zainal Abidin, Praktik Kompensasi dan Restitusi di Indonesia, sebuah Kajian Awal, ICW-ICJR, dan Koalisi Perlindungan Saksi, 2007.

Black's Law Dictionary, Sixth Edition

Undang-undang Nomor 26 tahun 2000 tentang Pengadilan Hak Asasi Manusia

Undang-undang Nomor 13 tahun 2006 tentang Perlindungan Saksi dan Korban

Peraturan Pemerintah Nomor 2 tahun 2002 tentang Tata Cara Perlindungan terhadap Korban dan Saksi dalam Pelanggaran Hak Asasi Manusia yang Berat.

Peraturan Pemerintah Nomor 3 tahun 2002 tentang Kompensasi, Restitusi, dan Rehabilitasi terhadap Korban Pelanggaran Hak Asasi Manusia yang Berat.

Peraturan Pemerintah Nomor 44 tahun 2008 tentang Pemberian Kompensasi, Restitusi dan Korban kepada Saksi dan Korban

Declaration of Basic Principles of Justice for Victims of Crime and Abuse of Power (adopted by General Assembly resolution 40/ 34 of November 1985) 